\title{
Marketing in the Age of the Coronavirus Infection Pandemic
}

\author{
Afanasyeva T.S. \\ Herzen State Pedagogical University of Russia \\ St. Petersburg, Russia \\ tafanasy@yandex.ru
}

\author{
Grishakina N.I. \\ Yaroslav-the-Wise Novgorod State University \\ Veliky Novgorod, Russia \\ gnisemm@mail.ru
}

\author{
Pokrovskaia N.N. \\ Herzen State Pedagogical University of Russia \\ Peter the Great St. Petersburg Polytechnic University \\ St. Petersburg Electrotechnical University "LETI" \\ Saint-Petersburg, Russia \\ nnp@spbstu.ru
}

\begin{abstract}
The relevance of this study is due to the fact that the whole world has changed due to COVID-19.This changed all business around the world.A new economic entity has arrived.A different marketing policy was needed.The Russian government noted that the Russian economy, like the rest of the world, was affected by the coronavirus. The Russian government claims that Russia is emerging from this crisis with the least losses compared to other countries and is providing significant assistance to the economy and the population of Russia.To eliminate the negative consequences of the coronavirus pandemic in the Russian economy, the Government of the Russian Federation is completely restructuring the economy, using innovative methods of doing business, providing medical assistance to citizens and has achieved impressive results. Russia is moving to a digital economy. Scientists and businesses note the need to change the way marketing agencies, departments and companies work, their structure and the need for them to use modern digital technologies. Most companies have reacted very differently to the pandemic.Some organizations were able to quickly navigate the changing circumstances, but for others the coronavirus has brought a lot of losses. The transition to selfisolation is associated with the emergence of new types of marketing: search engine marketing, coronamarketing, "ostrichmarketing" and others. The impact of digitalization on the marketing structure of the business is analyzed. It was necessary to find a relationship between digitalization and modern marketing in the context of a pandemic in the Russian Federation. The work of marketing agencies large and small in the age of the COVID-19 was investigated. The use of neural network technologies in marketing to improve the quality of business in the context of coronavirus is considered. A number of requirements are proposed for the structure of modern marketing departments, which they must meet.
\end{abstract}

Keywords-coronavirus, COVID-19, marketing, new economic entity, digitalization

\section{INTRODUCTION}

From century to century nothing changes, everything lives according to the principle: "Everything flows, everything changes". But the rate of change is very different. At the beginning of the 20th century, a terrible disease, the "Spanish flu", came to the world; according to various estimates, about 100 million people died. Almost 100 years later, a new coronavirus pandemic attack hit. Everything started changing rapidly.According to official data, as of December 4, $65,220,557$ people fell ill in the world, 1,506,251 people died.People either on their own or at the direction of the authorities are self-isolated, although now the demands of the authorities are weakening in some places. That is, people cannot work as they used to for one reason or another.In their work Afanasyeva \& Yurina (2019) noted that the profit of any company directly depends on the performance of people, on their comfortable, physical and psychological state.

The relevance of this study is due to the fact that the whole world has changed due to COVID-19. A new economic entity has arrived. A new marketing policy was required, the old one (Vasilyev, 2019) ceased to satisfy.

The Russian government noted that the Russian economy, like the rest of the world, has been affected by the coronavirus in many areas and different markets. The government adequately reacts to this and takes the necessary measures, which makes it possible to avoid the most negative scenario. Therefore, due to the COVID-19 pandemic in Russia, there will be no particular problems in the economy. The government of the Russian Federation argues that Russia is emerging from this crisis with the least losses compared to other countries. It is also completely restructuring the provision of medical care to the population and has already achieved impressive results. 
The pandemic has changed the business environment and, accordingly, marketing structures have ceased to work with the old proven methods. In particular, many marketing structures have switched to telecommuting/working remotely. The role of the Internet, of the work of marketers in it, has increased as never before, the need arose for a complete restructuring of the methods of work of marketing agencies, departments and companies, and their use of modern, innovative digital technologies.

\section{PROBLEM STATEMENT}

The main thing that has changed the whole world, all communications, business, economy, communication of people is the coronavirus pandemic. Different companies have responded to the pandemic in very different ways. Some Russian and foreign companies were able to quickly navigate the changing circumstances, but for others, the coronavirus brought a lot of losses.

Nevertheless, the chief economist of Alfa-Bank N. Orlova said that the annual income of the Russian GDP will not fall below $1.8 \%$ in 2020. The Moscow rating agency ACRA expresses the opinion that if the government properly responds to the decline in oil prices and the pandemic, there will be no serious economic consequences in the country.

Usually, a large number of tourists come to Russia, with about a million tourists from China per year. They come to Moscow, as well as to St. Petersburg and its environs, where it has become common to stand in long lines to enjoy the beauty of this museum city. The Chinese also visited our northern territories to see and admire the northern lights. But now the borders are closed, planes do not fly, therefore, many businesses are declining: tourism, hotels and restaurants incur losses, etc. This problem and many others were noted by the chairman of the State Duma Committee on the Financial Market Anatoly Aksakov. Many experts agree with him.

The demand for construction, especially elite construction, has also dropped; the property; luxury transport; some small business services.

Due to self-isolation, the transition to remote work, the lack of extra money from the population, many companies suffered losses, some went bankrupt, since they had no marketing plans and did nothing during the pandemic. This kind of marketing can be called "ostrich marketing". The same corporations that had a marketing plan, their work did not stop, and they switched to a search marketing strategy, continued to work more or less normally in a pandemic and suffered minimal losses.Linor Goralik, marketing consultant, introduced the concept of "coronamarketing", which has in its idea not only sales, but communication, memorability and its own image (Zazykin, 2019).

According to some studies, after the end of the main stage of the pandemic, those firms that increased their investments in marketing in the era of the coronavirus received minimal losses, or there were no losses, or they even made a profit.

From the above, it follows that the marketing strategy is essential and in the modern world it is necessary to adapt to the environment.

\section{RESEARCH QUESTIONS}

What changes have occurred in marketing, caused by the peculiarities of the business in the era of the coronavirus pandemic in the Russian Federation and other countries.

What modern digital technologies are used to promote marketing in Russia and in the world?

What gives the use of neural network technologies in marketing to improve the quality of work in organizations in the context of the crisis caused by the coronavirus pandemic.

How digital marketing can help overcome negative business conditions in a pandemic.

\section{PURPOSE OF THE STUDY}

The purpose of this work is to find out what problems in business have been caused by the coronavirus pandemic around the world and in Russia. In order to fulfill this purpose, it is necessary to consider what measures the Russian government is taking to eliminate the negative consequences of the coronavirus pandemic in the Russian economy. It is required to find the relationship between digitalization and modern marketing in the context of a pandemic in the Russian Federation.

It is required to consider in detail the modification of the structure of marketing agencies to promote and improve the work of the business, to identify trends in their development in recent years. There is a need to analyze how marketing in Russia functionally manages business in a pandemic.

What is the need for qualified marketing specialists, is there enough of them to work in a new economic entity, can they conduct economic and mathematical research of world-class business. Also, experts note that a generational change is coming, so they are very interested in the preferences of the younger generation.

\section{RESEARCH METHODS}

In this paper we used economic and mathematical, structural and logical research methods. Analytical processing of various documents, regulations, decrees and laws was carried out, a study and analysis of the latest sources of information was carried out. The work of marketing agencies large and small in a pandemic has been investigated. The application of neural network technologies in marketing to improve the quality of business in the context of the coronavirus is considered. The impact of digitalization on the marketing structure of the business is analyzed.

\section{FINDINGS}

Digitalization in the modern world community is a trend that has a lot of meanings (Smirnov, 2018).In 1995, American scientist Nicholas Negroponte described and used this word "digitalization". Digitalization presupposes, first of all, the use of digital, intelligent technologies to work in the modern economic space, and not only. Bagiev \& Yanenko \& Yanenko, 2017, explores the various challenges of a digital platform and marketing for businesses. The article by Khalin \& Chernova, 2018 analyzed in detail the impact of digitalization on the Russian economy, revealed its advantages and disadvantages over other research methods. There are a number of digital technology laboratories in Russia, for example, in Novosibirsk, where qualified specialists carry out mathematical as well as world-class economic research, carry out mathematical 
modeling of various economic objects, create new innovative projects to improve business performance in changed conditions.

It is impossible to stop progress, innovative methods and modern marketing tools are developing by leaps and bounds (Molchanov, 2019). Statistical studies were carried out on the economic situation in Russia (Ivanova \& Mahnitkina, 2019), which is necessary to analyze the work of enterprises in a pandemic. Digitalization of marketing (Nadtoka \& Matveev, 2017) makes it possible to optimize business in the era of a pandemic: quickly, better, economically, informatively. To achieve superiority over competitors, one should use digital marketing tools, apply modern innovative technologies. However, when using digital technologies in Russian business structures, a number of difficulties arise. NRU HSE, together with Microsoft, collected statistical data on the use and application of digitalization in 100 Russian business structures. Many problems have been identified that have arisen as a result of the use of digital technologies in the marketing of economic objects.

Tab. 1 presents the results of a survey on the use of digitalization in marketing.

In general, in the world, including in Russia, the use of new intelligent business methods is constantly increasing. The achievements of using digital technologies in marketing are especially visible.The main statistical programs are being updated, digitalization of marketing tools in the agro-industrial complex of the Russian Federation is widely used (Gusmanov et all, 2019).In his work (Galimov, 2019), Galimov examined how social networks are used to conduct marketing research in Russia and abroad.Multidimensional scaling, clustering, segmentation, and more are widely used.Big Data methods are widely used as a marketing tool.However, for a qualitative analysis and proposal, business structures require, in addition to highly qualified IT specialists, businessmen who are able to analyze and interpret the obtained numerical information, draw appropriate conclusions and make recommendations to business, especially in a pandemic.

Let's consider, for example, how a small marketing department was able to conduct marketing research and issue recommendations for a number of economic entities in the North-West of the Russian Federation. Back in 2011, the authors used the use of neural network technologies to study the dynamics of the functioning of markets with a non-linear development paradigm.

To carry out these studies, the authors suggested that the marketing agency conduct statistical research on the serviced enterprises, after which the data obtained were processed according to the methodology proposed by the authors. To use neural network technologies, the authors have developed a computer program No. 2010617039 (Certificate of state registration of the computer program No. 2010617039, 2010).

After analyzing the results obtained, the experts noted that it became possible to cluster and visualize all clients, both existing and potential. Expert assessments have confirmed the high results of the obtained predictive models for doing business. These predictive models made it possible, constantly receiving new statistical data, to build various forecasts, both long-term and short-term, and even receive instant forecasts. More details can be found in a book published in Germany (Manova \&
Grishakina \& Afanasyeva, 2012), which contains a program created and used by the authors.

TABLE 1. PRoblems ASSOCiATED WITH THE USE OF DIGITAL TECHNOLOGIES IN BUSINESS STRUCTURES IN RUSSIA

\begin{tabular}{|c|c|c|}
\hline $\begin{array}{l}\text { The nature of the } \\
\text { problem }\end{array}$ & $\%$ & Problem \\
\hline \multirow[t]{7}{*}{$\begin{array}{l}\text { Organizational } \\
\text { problems }\end{array}$} & 54 & $\begin{array}{l}\text { lack of experience } \\
\text { in creating and } \\
\text { implementing } \\
\text { digital projects }\end{array}$ \\
\hline & 49 & $\begin{array}{l}\text { incorrect estimate } \\
\text { of the deadline for } \\
\text { the completion of } \\
\text { work on this } \\
\text { project }\end{array}$ \\
\hline & 48 & $\begin{array}{l}\text { lack of qualified } \\
\text { staff }\end{array}$ \\
\hline & 48 & $\begin{array}{l}\text { lack of effective } \\
\text { communication } \\
\text { between different } \\
\text { departments }\end{array}$ \\
\hline & 83 & $\begin{array}{l}\text { there are no } \\
\text { business } \\
\text { strategies related } \\
\text { to digitalization } \\
\text { due to external } \\
\text { factors, that is, } \\
\text { insufficiently } \\
\text { developed } \\
\text { infrastructure, } \\
\text { unwillingness to } \\
\text { use digitalization }\end{array}$ \\
\hline & 55 & $\begin{array}{l}\text { businesses feel } \\
\text { that users are not } \\
\text { educated enough }\end{array}$ \\
\hline & 47 & $\begin{array}{l}\text { lack of interest } \\
\text { among users }\end{array}$ \\
\hline
\end{tabular}

Currently, there are ready-made software packages that allow using neural network technologies in marketing, this is especially important in the era of the coronavirus pandemic. The use of neural network technologies in marketing research provides significant opportunities for analyzing business and predicting the future at each stage of its development.

In 2016, in the small $(300,000$ people) Russian town of Veliky Novgorod, a number of entrepreneurs used the apparatus of neural network technologies in marketing to determine the best advertising medium from the proposed ones: advertising on $\mathrm{TV}$, the Internet, banners, sending to each citizen in the mailbox of a mini-newspaper advertisements for the sale of various goods and services. The preference for the latter advertising medium has been identified and shown in practice. Even in the midst of the pandemic, the townspeople did not stop receiving these mini-newspapers of ads, services and goods. Note that this marketing technique was identified for relatively small cities.

We will not describe all the business structures that suffered significant losses in the era of the pandemic, we will consider only a few of them. As is known, one of the most affected business structures in the Russian Federation is tourism. Air 
traffic with many countries has been suspended, flights to Turkey, beloved by Russians, began only on August 15, 2020. However, Russian travel agencies, after conducting marketing research, have developed new routes across the vast Russian expanses: this is Baikal, the Urals, and Arkhangelsk, and other very interesting routes. Moreover, the government participated in this development, offering the Russians cash benefits for compensation from 5,000 to 15,000 rubles per person, depending on the place and time. That gave some preferences to the railway and air transport of the Russian Federation, the development of regional economies. Also, domestic tourism contributed to the recovery of Russians without the threat of an external risk of contracting COVID-19, which is beneficial for the Russian economy.

Let us consider the IT business. According to Murachkovsky, director of the Moscow crowd platform, that in the era of the coronavirus pandemic, he does not have any special problems, this business has worked as it does.

The use of new digital technologies in marketing in Russia (Akhmetshin \& Ilyina \& Kulibanova \& Teor, 2019) also significantly helps in solving national projects developed by the government headed by Mikhail Mishustin (Arkhipova \& Kulikova \& Ilina, 2019).For example, in medicine, the digitalization of which takes the country to a new stage of service Installation of new equipment and digitalization, say in Saratov, significantly reduce the stay in a medical institution, most importantly, they reduce contacts between patients, which is especially important in the era of coronavirus, offer them the most advanced treatment. A survey of patients in Saratov showed that the patients were extremely satisfied.

Russian scientists have developed a number of vaccines against COVID-19, on August 11, 2020, it was registered, many citizens, including Mr. Zhirinovsky, and the daughter of the President of the Russian Federation, tested it. A leading Chinese epidemiologist called this coronavirus vaccine very good and praised it highly. In the near future, teachers and doctors, as the most vulnerable, by virtue of their profession, Russians, will receive the vaccination. Then the people from a group of special risk will be vaccinated. This and many other things, for example, masks, special preparations, will make it possible to get out of this situation with the least loss and improve the economy of the Russian Federation. What is remarkable is that today's youth has responded to the challenges of the time: this year there is an unusually high competition for medical institutes.

It should be noted that the largest competition in 2020 at Moscow State University and other large universities was in the departments of computational and applied mathematics and computer science. Also, what makes one glad, in many economic universities, the specialty of economist-analyst is in great demand. However, this specialty is not available in all regional universities, which sometimes pay insufficient attention to mathematics and its applications.

One can talk a lot about the economy of the Russian Federation in the era of coronavirus, note that everything is not so upsetting (Nikiforova \& Lavrentiev, 2019). The increased role of volunteers in Russia should be noted. It is interesting that the number of cases in the Russian Federation every day at the present time is becoming less than the number of those who recovered, and about $20 \%$ get sick with coronavirus in a mild form.
Marketing is starting to work in a new way. It should be borne in mind, however, that its tasks are basically the same as they have always been, although now marketing is especially inseparable from digitalization.

As a result of the above, we offer a diagram of marketing structures.

Modern marketing structures must meet the following requirements:

- employees must be able to use digital marketing tools, i.e be qualified IT specialists and have a quality education;

- in order for an economic entity to be competitive, it is necessary to preserve and increase digital content;

- there must be an economist-analyst in each department, capable of giving an economic interpretation of the obtained mathematical information, making the necessary decisions promptly, contacting clients on time, but at present there is a lack of a proper number of such specialists in the Russian Federation;

- either each marketing structure should have its own statistics departments, or there should be close contact with individual statistics departments that conduct the testing and polls necessary for the work of marketing structures;

- communications of all departments of the enterprise and marketing agency must be coordinated with each other;

- there must be modern computer equipment and an established connection to the Internet;

- as life has shown, telecommuting/remote work for marketing employees is also possible for many reasons: coronavirus, lower cost of funds, greater payback, convenience for workers with small children, time to travel to work.

This scheme is relevant for all marketing agencies and marketing departments in large companies. In the case of a small business, there must be at least one IT specialist, and the role of an analyst can be played, for example, by the manager themself.

\section{CONCLUSION}

Currently, one of the main marketing tools is economic and mathematical methods. Digitalization has gone deep into marketing for a long time, if not forever. It should also be noted that there is an increase in the use of neural network technologies in marketing, the use of which provides significant advantages, especially in the era of the coronavirus pandemic.

When conducting marketing research, especially in the era of coronavirus, when many agencies have switched to remote work, one is to adhere to the scheme developed in this article.

\section{Acknowledgments}

The research was carried out with the financial support of the Russian Foundation for Basic Research within the framework of the grant project no. 16-29-12965\18. 


\section{References}

[1] T.S. Afanasyeva and N.N. Yurina, "Marketing At The Time Of Sustainable Development Of Russia", The European Proceedings of Social and behavioral Sciences, 2019.

[2] S.V. Vasilyev, "Modern Trends In The Development Of Science Management", The European Proceedings of Social and behavioral Sciences, 2019, vol. 17(81-899), pp.153-160.

[3] V.G. Zazykin, "Image of the organization: structure and psychological factors of efficiency". Retrieved from: http: // www.tandem-forum.ru [in Russ.].

[4] G.L. Bagiev, M.B. Yanenko and M.E. Yanenko, "On The Issue Of Formation And Improvement Of A Digital Platform For Organizing And Managing A Company's Marketing Activities: Problems And Tasks", Problems of the modern economy, 2017, vol. 2. Retrieved from: http://www.m-economy.ru/art.php?nArtId=6076.

[5] V.G. Khalin and G.V. Chernova, "Digitalization And Its Impact On The Russian Economy And Society: Advantages, Challenges, Threats And Risks", Management Consulting, 2018, vol. 10. Retrieved from: https://cyberleninka.ru/article/n/tsifrovizatsiya-i-ee-vliyanie-narossiyskuyu-ekonomiku-i-obschestvo-preimuschestva-vyzovy-ugrozy-iriski.

[6] N.N. Molchanov, "Marketing Of Innovations In 2 Hours", Part 1: textbook and workshop for academic bachelor's degree, Moscow: Yurayt Publishing House, 2019, $257 \mathrm{p}$

[7] I.A. Ivanova and O.V. Mahnitkina, Modern Information Technologies Are In Sociological Researches, 2019. Retrieved from: https://novainfo.ru/article/3709.

[8] T.B. Nadtoka and N.V. Matveev, "Transformation Of Marketing Activities Of Enterprises In The Digital Economy", Bulletin of the
Institute of Economic Research, 2017, vol. 4. Retrieved from: https://cyberleninka.ru/article/n/transformatsiya-marketingovoydeyatelnosti-predpriyatiy-v-usloviyah-tsifrovoy-ekonomiki.

[9] R.U. Gusmanov, A.R. Kuznetsova, E.V. Stovba and M.R. Avzalov, "Newparadigm Of The Economic Development Of The Regional Rural Territories", The European Proceedings ofsocial and behavioral Sciences, 2019, vol. 17, pp.206-217. DOI: 10.15405/epsbs.2019.04.24

[10] R.R. Galimov, "Domestic And Foreign Experience Of Marketing Research In Social Networks Of The Internet". Retrieved from: http://naukarus.com/otechestvennyy-i-zarubezhnyy-opyt-provedeniya arketingovyh-issledovaniy-v-sotsialnyh-setyah-interneta.

[11] Certificate of state registration of the computer program No. 2010617039 , Russian Federation, Research of the dynamics of the functioning of markets using neural networks, Novgorod State University named after Yaroslav the Wise, vol. 2010617039.

[12] N.V. Manova, N.I. Grishakina and T.S. Afanasyeva, "Marketing Research", Publishing house LAP, 2012, 298 p.

[13] E.M. Akhmetshin, I.A. Ilyina, V.V. Kulibanova and T.R. Teor, "Special aspects of master data-based integrated management of region reputation in modern IT environment", IOP Conference Series: Material Scince and Engineering. DOI: 10.15405/epsbs.2019.04.10

[14] L.S. Arkhipova, E.I. Kulikova and A.I. Ilina, "Diagnostics Of The Production Potential Of The Regions Of Russia", The European Proceedings ofsocial and behavioral Sciences, 2019, vol. 17, pp.109-122. DOI: $10.15405 /$ epsbs.2019.04.13

[15] E.P. Nikiforova and D.A. Lavrentiev, "Non-Profit Organization Management Principles: Mechanics And Specificities", The European Proceedings of S social and behavioral Sciences, 2019, vol. 17, pp. 261270. DOI: $10.15405 /$ epsbs.2019.04.30 